\title{
28 Research Square \\ Redefining Waters of the US: A Case Study from the Edge of the Okefenokee Swamp
}

C Rhett Jackson ( $\square$ rjackson@warnell.uga.edu )

University of Georgia https://orcid.org/0000-0001-6165-3556

\section{Caleb Sytsma}

University of Georgia

Lori A. Sutter

University of Georgia

Darold P. Batzer

University of Georgia

\section{Research Article}

Keywords: wetlands, streams, Clean Water Act, policy

Posted Date: August 9th, 2021

DOI: https://doi.org/10.21203/rs.3.rs-682291/v1

License: (1) This work is licensed under a Creative Commons Attribution 4.0 International License. Read Full License

Version of Record: A version of this preprint was published at Wetlands on November 3rd, 2021. See the published version at https://doi.org/10.1007/s13157-021-01512-8. 


\section{Abstract}

Defining the upslope extent of Federal Clean Water Act jurisdiction over wetlands and streams has been contentious since the passage of the Act but has large effects on the type, number, and area of wetlands that are protected by legislation. Federal guidance in the US has changed and evolved in response to scientific knowledge, Supreme Court decisions, and policy goals of Presidential Administrations. In 2020, the Trump administration replaced the Obama administration Clean Water Rule with the Navigable Waters Protection Rule with the goal of reducing jurisdiction over so-called isolated depressional wetlands and small streams. Here we use a case study of a titanium sands mining proposal on Trail Ridge southeast of Okefenokee Swamp to illustrate the large reduction in wetland and stream protection engendered by this policy change. Under the Navigable Waters Protection Rule, all seven wetlands within the 232 ha mining area, totaling 131 ha or $56 \%$ of the project area, were deemed non-jurisdictional and thus the project required no federal review or permitting. Under an earlier mining application under the Clean Water Rule, all of these wetlands were declared jurisdictional. Trail Ridge is located on the Atlantic Coastal Plain, an ecological province rich in depressional wetlands and ill-defined surface drainages. This case study shows that in such environments, the Navigable Water Protection Rule will allow destruction of large numbers and areas of ecologically significant wetlands.

\section{Introduction}

Since the Clean Water Act (CWA) was passed in the 1970s, interpretations of the extent of Federal jurisdiction over wetlands and streams in the US have evolved in response to political considerations, Supreme Court decisions, changes in direction from each Presidential Administration, and changes in technical guidance from regulatory agencies. The Clean Water Act, under Federal authority granted by the Interstate Commerce Clause of the Constitution, seeks to protect the physical, chemical, and biological integrity of the Nation's Waters. What constitutes the Nation's Waters, however, has been open to considerable interpretation. In January 2020, the US Environmental Protection Agency (USEPA) under the Trump Administration, headed by Andrew Wheeler, enacted the "Navigable Waters Protection Rule" (NWPR) which contracted the physical extent of federal jurisdiction over wetlands and streams. It has been predicted that the NWPR will leave a substantial fraction of the nation's wetlands and streams, in particular isolated wetlands and small stream channels, unprotected. Estimates of the fraction of aquatic features that would no longer receive protection include $50 \%$ of wetlands and $20 \%$ of streams (Sullivan et al. 2019) and $43-56 \%$ of stream channels (Fesenmyer et al. 2021). The NWPR replaced the Clean Water Rule (CWR) previously developed and implemented during the Obama Administration, and the resulting change is expected to have substantial effects on the scope of Federal wetland protection. Here we use a single case study - a proposed titanium sands mining operation on Trail Ridge between the Okefenokee Swamp and the coast in the lower Coastal Plain of Georgia - to illustrate the types and amounts of aquatic features of the Coastal Plain that are no longer protected by the CWA under the NWPR.

\section{Evolution of CWA Jurisdiction and the Path to the Navigable Waters Protection Rule: An Overview}

The 1972 amendments to the Federal Water Pollution Control Act (now known as the Clean Water Act) created jurisdiction over federal waters. This legislation regulates the discharge of pollutants (dredge and fill are defined as pollutants) into navigable waters, specifically "waters of the United States, including the territorial seas" (U.S.C. $\S$ 1362). Defining this phrase has been the subject of debate and interpretation for five decades and is the subject of many books and legal and policy analyses (Gardner 2011; Sutter et al. 2015; Mihelcic and Rains 2020). The US Corps of Engineers (USACE) specified that these waters include "wetlands adjacent to [other] waters" (33 CFR § 328.3(a)(7)) and further defined wetlands as "those areas that are inundated or saturated by surface or ground water at a frequency and duration sufficient to support...a prevalence of vegetation typically adapted for life in saturated conditions. Wetlands generally include swamps, marshes, bogs, and similar areas" (33 CFR § 328.3(b)). Traditional interpretations

Page 2/13 
of navigable waters stemming from the Rivers and Harbors Act of 1988 have included that a waterway be navigable in fact, in the past, in the future with reasonable improvements, or subject to tidal ebbing and flooding.

Between 1987 and 2004, regulatory interpretations of Waters of the United States (WOTUS) stabilized somewhat, but since 2004 WOTUS interpretations have swung widely in response to Federal Court decisions about jurisdictional limits as well as changes in policy priorities by the Trump administration. Highlights of key Supreme Court decisions that are most important to CWA jurisdiction follow.

In 1985, the Supreme Court began exploring the regulatory extent of the CWA. The United States had sued Riverside Bayview Homes, Inc for filling wetlands adjacent to Lake St. Clair (Michigan). The defendant argued that denial of the ability to fill the property constituted a taking without just compensation. The 1985 Supreme Court decision led to the inclusion of wetlands adjacent to traditional navigable waters as wetlands are "inseparably bound up" with navigable waters and "in the majority of cases" these wetlands hold "significant effects on water quality and the aquatic ecosystem", such as those adjacent to lakes and estuaries as WOTUS and subject to regulatory regulations regarding polluting US waters.

Following the Riverside Bayview case, agencies involved in wetlands regulation took part in rulemaking to implement the CWA, where they interpreted the Code of Federal Regulations to hold jurisdiction over all waters used by migratory birds that cross state lines. This effort resulted in the "Migratory Bird Rule" that they promoted as a clarification to the definition of WOTUS, rather than a re-definition of it. Because migratory birds cross state borders, they fall under the Interstate Trade clause in the Constitution. A case having nothing to do with wetlands (US v Lopez) challenged the limits of interstate commerce and resulted in that rule being narrowed to "(1) regulation of channels of commerce, (2) regulation of instrumentalities of commerce, and (3) regulation of economic activities which not only affect but "substantially affect" interstate commerce." (USCRS 2014)

The Solid Waste Agency of Northern Cook County (SWANCC), a consortium of Illinois municipalities, sued the USACE for denying SWANCC a permit to build a landfill in areas containing small, isolated ponds and wetlands. The USACE argued that these abandoned pits had since naturally filled with water and consequently supported migratory birds, thus invoking the Migratory Bird Rule. In the 5-4 decision of 2001, the Supreme Court rejected the argument that the USACE held jurisdiction over these isolated wetlands for bird use, suggesting that invoking it overextended federal authority on non-federal lands. Congress, the Court held, in its use of navigable waters "has at least the import of showing us what Congress had in mind for enacting the [Act]: its traditional jurisdiction over waters that were or had been navigable in fact or which could reasonably be made so" (SWANCC, 531 U.S. at 172-4). The ponds that had formed after pits were abandoned were, in fact, not connected to navigable waters because they lacked a "significant nexus" to traditionally navigable waters.

Significant nexus became a critical term in determining whether wetlands are waters of the US. In Michigan, a developer named Rapanos wished to fill wetlands for a shopping center, but the state Department of Environmental Quality informed him that these areas were protected from fill under protective laws. Rapanos continued to fill the wetlands and then ignored a cease and desist order from the USEPA. The US government brought suit against him, but Rapanos argued that these wetlands were not waters of the US because they were not navigable. The Supreme Court decision of 2006 consisted of a 4-4-1 vote, with the lone Justice Kennedy suggesting that these wetlands might be under jurisdictional authority if there were evidence of a significant nexus between them and navigable waters.

"Significant nexus" thus became the key concept in defining CWA jurisdiction, and differing interpretations of nexus led to the disparate guidance of the Obama administration CWR and the Trump administration NWPR.

\section{Case Study Description}


A recent proposal to mine titanium-rich sands on Trail Ridge to the southeast of the Okefenokee National Wildlife Refuge in Georgia (USA) provides a case study of how the shift from the CWR to the NWPR has reduced the scope of Federal wetland jurisdiction, particularly over isolated wetlands. This case study will also illustrate how the uncertain determination of flow status of surface drains is now critical to CWA jurisdiction. Twin Pines LLC, a mining company, first applied for permits for mining approximately 973 ha on Trail Ridge in 2017, while the CWR was in effect. After the NWPR was published in January 2020, Twin Pines LLC retracted the earlier and larger application that had been reviewed under the CWR, and they submitted a new mining application to be reviewed under the NWPR.

Correspondence between the US Army Corps of Engineers and the applicant indicates the two parties worked to refine the mining proposal to minimize wetland impacts, as is appropriate in CWA permitting. Finally, in the fall of 2020, Twin Pines submitted a first phase permit application for a contiguous mining area of 232 ha including 131 ha of wetlands and the headwaters of several water courses (Figure 1). The total operations area covered 298 ha, including areas for processing and handling of the titanium sands. The USACE re-determined jurisdiction over many wetlands under the new rules. By comparing these determinations, we can characterize and quantify the effects of the rule change on jurisdictional determinations in this landscape.

Trail Ridge was formed (144 Ma) as a barrier island complex during higher sea levels (Force and Rich 1989; Adams et al. 2010). It runs 160 kilometers parallel to the coastline from near Hoboken, Georgia to the vicinity of Starke, Florida. The formation of Trail Ridge blocked several small rivers flowing to the Atlantic, causing a backwater effect until waters flowed either south through a gap in Trail Ridge (in what is now the Saint Marys River) or west to the Gulf Coast through the Sewanee River. This damming effect of Trail Ridge created the Okefenokee Swamp and partly motivates the particular concern for this area of the ridge. The Ridge is typically $1-2 \mathrm{~km}$ wide and 20-50 m higher than the surrounding landscape. Slopes are very gentle, and one does not sense being on a ridge at the top (less than $2 \%$ slopes). Rivers passing from the Upper Coastal Plain to the Atlantic bisect the ridge in several places. Trail Ridge is composed largely of marine sands that are high in titanium oxide (Force and Rich 1989), and this is the reason the ridge is attractive for mining. The ridge has been extensively mined for decades farther south in Florida, from Interstate 10 down to Starke, FL.

The soils of Trail Ridge are spodosols, meaning they have a humic B horizon. Twenty percent of the soils in the proposed mining area are mapped as either Lynn Haven, Allanton, or Kingsferry, ponded, series that are very poorly drained and estimated to be ponded for 2-6 months annually (Web Soil Survey Staff n.d.). Frequently ponded Leon fine sands cover another two percent of the site, and these are also considered very poorly drained. Depressional wetlands on these uplands tend to be wettest in the winter, when evapotranspiration is low, water tables are high, and soils are saturated near the surface. These wetlands often overflow through swales and enter streams for weeks to months at a time during wet periods (Wilcox et al. 2011; Lee et al. 2020). The USGS and EPA map an intermittent or perennial stream starting in the wetlands in the southeastern portion of the site and draining east into Boone Creek and then the St. Marys River.

Trail Ridge acts as an internal drainage divide in the St. Marys River basin. Water from the mine site drains in part through the river's headwaters in the Okefenokee Swamp Wilderness Area to the west (A Ramsar Convention wetland of international importance), and also to other tributaries of the St. Marys River to the east and south. The St. Marys River forms part of the Georgia-Florida border and drains into Cumberland Sound of the Atlantic Ocean, past Cumberland Island National Seashore.

Waters in the St. Marys River basin are currently classified as having values for fishing, recreation, drinking water, or wild and scenic uses (GA DNR 2002). Thus, the proposed project has the potential to impact a range of resources, of considerable local, state, national and even international interest. Concern for the ecological integrity of the 
Okefenokee Swamp and its margins has also motivated opposition to past mining proposals in this area. The USFWS (2019) has noted that this portion of Trail Ridge provides habitat for gopher tortoises (an ESA candidate species), indigo snakes (threatened), and several amphibian species of concern. The USFWS letter expressed concern that the reconstituted soils created after mining would not provide habitat for these species and recommended that an Environmental Impact Study (EIS) be required for the earlier, larger mining application. Similarly, the USEPA determined that the previously proposed project would "have a substantial and unacceptable impact on aquatic resources of national importance" (USEPA 2019).

\section{Methods}

Analysis was reliant on publicly-available USACE-verified maps created by Twin Pines LLC as well as public GIS databases. Most permitting documents were publicly available, and the remainder were sourced from the Southern Environmental Law Center, which obtained the through Freedom of Information Act requests.

The mining tract polygon, USACE-verified wetland polygons, and USACE-verified stream lines shown in Figure 1 were created by georeferencing PDFs of TTL maps with the FreehandRasterGeoreferencer plugin (Vellut and Mizutani 2021) for QGIS version 3.18.1 (QGIS Development Team 2021). Map PDFs were added to QGIS as raster files and adjusted with the following three steps using the georeferencer tool interface. First, the transparency was adjusted to show an imagery basemap behind the raster. Second, the raster was moved, rotated, and adjusted so that roads and pine forestry tract borders shown on the PDF's imagery matched the same features on the basemap. Third, the northwest and southeast corners of the raster were used for georeferencing, and the resulting adjusted and georeferenced raster was exported. Base QGIS tools were then used to create new shapefile layers for the proposal boundary, wetlands, and streams shown on the georeferenced raster. Acreages calculated with the QGIS field calculator for traced wetlands did not match USACE-verified acreages. As such, Figures 1 and 2 are for illustrative purposes only, and USACE-verified values for stream lengths and wetland areas are used for all calculations and analyses.

Wetlands shown in Figure 1 as "CWR Wetlands" were traced from USACE-verified TTL maps dated November 2019. Wetlands shown in Figure 1 as "NWPR Wetlands" were traced from USACE-verified TTL maps dated October 2020. Streamlines shown in Figure 1 as "USACE-Verified Streams" were originally traced from TTL maps dated July 2019, although symbology is based on the most recent USACE-verified maps they were included in. This was done to include ditches and wetland swales, which were removed from TTL maps following USACE verification. Additional USGS streamlines labelled "NHD Streamlines" are National Hydrography Dataset (NHD) line features added from the NHDPlus HR geodatabase for HUC-0307. Imagery-derived wetland polygons in Figure 2 are from the National Wetlands Inventory (NWI). USACE-verified stream and wetland extents shown on Figure 1 are more accurate than imagery and DEM-derived stream and wetland extents sourced from the NHD and NWI.

\section{Findings}

The relatively flat surface of the ridge features numerous depressional wetlands (Figures 1 and 2). Under the CWR, every one of the numerous wetland features in the previously proposed 973 ha permit area was deemed jurisdictional by the USACE. Thus the application would have required a $\$ 404$ permit requiring mitigation for eliminating these wetlands.

In October 2020, under their interpretation of the NWPR, the USACE determined that none of the aquatic features in the modified 298 ha permit area fell under federal jurisdiction and thus no federal review or permitting was necessary. Considering only the currently proposed 232 ha mining area, the applicants and the USACE mapped seven separate 
depressional wetlands totalling 131.01 ha, covering over $50 \%$ of the mining area (Figure 1). Portions of some of these wetlands extend beyond the permit boundary (Figure 1).

The seven wetlands within the proposed 232 ha mining area were judged to have no connection to intermittent or perennial streams, although three of these wetlands, totalling $106.55 \mathrm{ha}$, are connected to downstream waters via drains determined to be either ditches or ephemeral swales. Under the NWPR, direct surface connection of a wetland to an intermittent or perennial stream, or location on the floodplain of a perennial stream, is necessary to fall under CWA jurisdiction. Under the NWPR, ditches and ephemeral swales are not jurisdictional connections of wetlands to downstream waters. Field inspection of the ditch and swale flowing south on May 29, 2021 found no standing or flowing water but did find hydric soils at the surface, indicating seasonal saturation of extended duration. Even at the top of the ridge, groundwater levels are very near the ground surface according to the hydrogeologic investigation done by the applicant (Holt et al. 2020), so it is logical that groundwater excess flow would move through the drains in the wet season. The swale to the southeast featured a bed of exposed mineral soil, with vegetation wrested by the normal flow of water, and thus met the definition of a stream in the State of Georgia. The ditch that flows east from the proposed mining area is mapped as a stream on historical highway maps of the area and in the National Hydrography Database (Figures 1 and 2).

As the applicant and the USACE negotiated a mining proposal under the provisions of $\S 404$ of the CWA, seven other depressional wetlands outside the current mining proposal were also reassessed under the NWPR following earlier jurisdictional determination under the CWR. These seven wetlands, totaling 15.3 ha, were also judged to be unconnected to intermittent or perennial streams and thus unprotected by the CWA (Figure 1). Three of these wetlands are connected to an identifiable drainage path, but this drainage path was deemed to be a ditch, although it is not straight and does not follow a road or other utility (Figure 2). Silvicultural ditching to reduce groundwater levels is an acceptable practice under the CWA, but silvicultural ditches are typically straight and regularly-spaced. This ditch does not appear to be a historical silvicultural ditch.

\section{Policy Implications}

The history of titanium sands mining on Trail Ridge illustrates how environmental laws and regulations affect land management. Titanium mining on Trail Ridge south of Interstate 10 in Florida began in the late 1940s, decades before passage of the Clean Water Act. The density of depressional wetlands did not pose a permitting, compensatory wetland mitigation, or reclamation problem for mining companies prior to the CWA.

Passage and implementation of the CWA has deterred titanium mining of Trail Ridge in Georgia near the Okefenokee Swamp on several occasions. In the 1990s, Dupont Corporation proposed to mine titanium on 38,000 acres of Trail Ridge east of the Okefenokee and north of the presently proposed operation. Then Secretary of Interior Bruce Babbitt toured the swamp and publicly proclaimed Federal government opposition to the project. Given the public opposition and difficulties of permitting the project under the rules of that time, Dupont abandoned the proposal, donated 16,000 acres of land to The Conservation Fund, of which 7000 acres were then added to the Okefenokee National Wildlife Refuge, and then sold the rest of the land.

Prior to the NWPR, Twin Pines had submitted an application for a larger mining project of 973 ha, but it would have required extensive mitigation, and USACE had recommended that an EIS be required for the project. In addition, USEPA and USFWS both wrote letters indicating opposition or serious reservations about the project (USEPA 2019; USFWS 2019). The USFWS letter pointed out that this area of Trail Ridge provides habitat for several ESA threatened or candidate species including the gopher tortoise (Gopherus polyphemus), the indigo snake (Drymarchon couperi), and 
the flatwoods salamander (Ambystoma cingulatum). Under the CWR, it appears that permitting a titanium mine in this wetland-rich location would have been difficult.

At this site, the regulatory consequences of replacing the CWR with the NWPR were large and consequential. Under the CWR, all 131 ha of depressional wetlands on the 232 ha proposed for mining were deemed to be jurisdictional, but under the NWPR, none of these wetlands were deemed jurisdictional. Thus, no Federal review or permitting is required for the 232 ha mining proposal.

The NWPR represents a major shift in US wetland policy, essentially abandoning the "no net loss" of wetlands policy of the George H.W. Bush administration. This case study vividly illustrates that the NWPR provides no protection for depressional wetlands that lack irrefutable surface connection to intermittent and perennial streams. This is not a policy glitch, reducing the scope of wetland and stream protections is an intended consequence of the NWPR rule as evidenced by the press release that accompanied the publication of the rule (USEPA 2020). In this press release, EPA Administrator Andrew Wheeler is quoted, "EPA and the Army are providing much needed regulatory certainty and predictability for American farmers, landowners and businesses to support the economy and accelerate critical infrastructure projects." In the same press release, R.D. James, Assistant Secretary of the Army for Civil Works says "This rule also eliminates federal overreach and strikes the proper balance between federal protection of our Nation's waters and state autonomy over their aquatic resources. This will ensure that land use decisions are not improperly constrained, which will enable our farmers to continue feeding our Nation and the world, and our businesses to continue thriving." Internal to these agencies, this rule change was controversial. Prior to publication of the NWPR, EPA's Science Advisory Board (SAB) "concluded that the proposed WOTUS rule does not incorporate best available science and as such we find that a scientific basis for the proposed Rule, and its consistency with the objectives of the Clean Water Act, is lacking." (USEPA SAB 2020).

Without Federal jurisdiction over the wetlands and streams in the proposed mining area, all permitting responsibilities fall to the state and the county. The State of Georgia has no laws protecting freshwater wetlands, nor does Charlton County, so in this case the wetlands have no legal protections and thus their destruction will require no mitigation. Only 24 of the 50 states in the US have laws protecting freshwater wetlands (though the level of protection varies widely), so in the majority of the country, protection of freshwater wetlands comes only from the CWA (Kusler and Christie 2006).

Under the NWPR, classification of the type and flow status of surface drainage features is crucial to the determination of wetland jurisdiction (Fesenmeyer et al. 2021; Golden et al. 2017). Unfortunately, determination of flow status of surface drainage features by short field inspections is very difficult (e.g. Svec et al. 2005; Nadeau et al. 2015; Fritz et al. 2013). Streams that have been classified as ephemeral by the USGS often flow for over half of the year (Svec et al. 2005). Research is needed to guide estimation of the flow status of drains in flat topography (e.g. Epting et al. 2018; Jones et al. 2019). The NWPR defines ephemeral streams as "surface water flowing or pooling only in direct response to precipitation (e.g., rain or snow fall)." By this definition, even a stream that flows continuously for just a few weeks a year during the wet season is an intermittent stream. Drainages that flow only in response to precipitation will not be saturated long enough to develop hydric soils in the bed. At this site, however, at least two drainages with hydric soil conditions were not judged to be intermittent streams. Without scientific guidance and standards for judging flow conditions during short site visits, there is a high degree of arbitrariness in jurisdictional determinations.

\section{Ecosystem Service Implications}

Headwater streams and small wetlands provide an assortment of ecosystem services (Millennium Ecosystem Assessment 2005), at both local and regional (watershed) scales (Colvin et al. 2019). Most interactions between 
uplands in a watershed, and the main channel of a stream or river occur through headwater streams and wetlands (Golden et al. 2017). While rivers have been called the arteries of a landscape, headwater streams and wetlands are considered the capillaries (USGS 2021), and are where uplands and aquatic systems functionally interact (Freeman et al. 2007; Liebowitz et al. 2018). Rainfall that falls within a watershed filters through wetlands, soils, and headwater streams (Cohen et al. 2016; Golden 2016). These habitats contribute materials essential to downstream river functions (Freeman et al. 2007; Meyer et al. 2007; Wipfli et al. 2007; Liebowitz et al. 2018), while simultaneously filtering out unwanted contaminants entering from uplands (Marton et al. 2015). Headwater streams and small wetlands are connected to surficial groundwater aquifers, and both groundwater discharge and recharge functions operate at these locations (Jackson et al. 2014). In Coastal Plain watersheds, small depressional wetlands comprise a large portion of the active storage feeding the stream system (Jones et al. 2018; Lee et al. 2020). From a hydrological perspective, the entire landscape is connected to navigable waters, and consequently actions that affect water quality anywhere in the landscape affect water quality in navigable waters. The jurisdictional boundary used in the application of the CWA is largely arbitrary. In north Florida, near the Twin Pines project, small depressional wetlands have been empirically shown to provide important water storage services across the landscape (Lane and D'Amico 2010). If headwater streams or wetlands are eliminated, as proposed by the Twin Pines project, water quality and quantity will be affected locally and downstream (Golden et al. 2016).

Small headwater streams (Meyer et al. 2007; Colvin et al. 2019) and small depressional wetlands (Semlitsch and Bodie 1998; Cohen et al. 2016; Kirkman et al. 2016; Biggs et al. 2017) support a biodiversity (plants, invertebrates, fishes) not found in larger habitats, and some of this biodiversity is threatened. Across the Southeastern Coastal Plain, Edwards and Weakley (2001) found that 200 plant species of special concern were associated with depressional wetlands, with 69 of these species labeled as being threatened. Depressional wetlands of the Southeastern US Coastal Plain also support amphibians of special concern, with flatwoods salamanders (Ambystoma cingulatum and Ambystoma bishopi) being Federally protected (Gorman et al. 2009), the striped newt (Notophthalmus perstriatus) being listed as threatened in Georgia and Florida (Johnson 2002), and the gopher frog (Rana capito) being considered for listing (Gregoire and Gunzburger 2008). These amphibians find the fishless status of many depressional wetlands conducive to breeding success (Gregoire and Gunzburger 2008). In the southeastern US, an important nexus exists between larger streams and rivers and nearby small wetlands via gravid female alligators (Alligator mississippiensis) seeking out depressional wetlands to nest and raise their young until the hatchlings are large enough to return to the larger aquatic habitats (Subulasky et al. 2009). Again, if headwater streams or wetlands are eliminated, as proposed by the Twin Pines project, ecosystem services provided by biodiversity will be impaired. As mentioned by USFWS (USFWS 2019), upland biodiversity may also be imperiled.

\section{Conclusions}

This case study shows that in geologic environments rich in depressional wetlands and ill-defined surface drainages, the Navigable Water Protection Rule will allow destruction of large numbers and areas of ecologically significant wetlands. Consequently, protection for upland depressional wetlands will fall to the states, many of which do not have specific laws prohibiting destruction of such wetlands. Under the NWPR, the determination of jurisdiction depends upon the assessment of whether connecting drains flow ephemerally or at least intermittently. Such a determination is difficult based on short visits unsupported by stream monitoring, and thus the determination of CWA jurisdiction over headwaters and adjacent depressional wetlands under the NWPR is somewhat capricious in current practice.

\section{Declarations}

\section{Acknowledgments}


The Southern Environmental Law Center assisted us with understanding the timeline of this permitting process and provided us with copies of relevant documents from the permitting process. Darold Batzer is supported by the USDA Hatch Program. This work was partly supported by the USDA McEntire-Stennis program.

Funding This work was not supported by a specific grant, but partial support was provided by the USDA Hatch and McEntire-Stennis programs.

\section{Conflicts of interest/Competing interests None.}

Ethics approval Not applicable.

Consent to participate Not applicable.

Consent for publication Not applicable.

Availability of data and material Most of the records used in this analysis are publicly available. Some of the permitting correspondence was obtained by the Southern Environmental Law Center through the Freedom of Information Act. The corresponding author can be contacted for files that can't be found in the public record.

Code availability Not applicable.

Authors' contributions CRJ, CSA, LAS, and DPB together scoped this analysis, interpreted the data together, and contributed to the writing and editing. CS did the GIS work and mapping.

\section{References}

1. Adams PN, Opdyke ND, Jaeger JM (2010) Isostatic uplift driven by karstification and sea-level oscillation: Modeling landscape evolution in north Florida. Geology 38:531-534. doi:10.1130/G30592.1

2. Biggs J, von Fumetti S, Kelly-Quinn M (2017) The importance of small waterbodies for biodiversity and ecosystem services: implications for policy makers. Hydrobiologia 793:3-39. doi:10.1007/s10750-016-3007-0

3. Cohen MJ, Creed IF, Alexander L, Basu NB, Calhoun AJK, Craft C, D’Amico E, DeKeyser E, Fowler L, Golden HE, Jawitz JW, Kalla P, Kirkman LK, Lane CR, Lang MW, Leibowitz SG, Lewis DB, Marton J, McLaughlin DL, Mushet DM, Raanan-Kiperwas H, Rains MC, Smith L, Walls SC (2016) Do geographically isolated wetlands influence landscape functions? Proceedings of the National Academy of Sciences 113:1978-1986. doi: 10.1073/pnas. 1512650113

4. Colvin SAR, Sullivan SMP, Shirey PD, Colvin RW, Winemiller KO, Hughes RM, Fausch KD, Infante DM, Olden JD, Bestgen KR, Danehy RJ, Eby L (2019) Headwater streams and wetlands are critical for sustaining fish, fisheries, and ecosystem services. Fisheries 44:73-91. doi:10.1002/fsh.10229

5. Edwards AL, Weakley AS (2001) Population biology and management of rare plants in depression wetlands of the southeastern coastal plain, USA. Natural Areas Journal 21:12-35

6. Epting SM, Hosen JD, Alexander LC, Lang MW, Armstrong AW, Palmer MA (2018) Landscape metrics as predictors of hydrologic connectivity between Coastal Plain forested wetlands and streams. Hydrol Process 32:516-532. doi:10.1002/hyp.11433

7. Fesenmyer KA, Wenger SJ, Leigh DS, Neville HM (2021) Large portion of USA streams lose protection with new interpretation of Clean Water Act. Freshwater Science 40:252-258. doi:10.1086/713084

8. Force ER, Rich FJ (1989) Geologic evolution of Trail Ridge eolian heavy-mineral sand and underlying peat, northern Florida. U.S. Geological Survey Professional Paper 1499. doi: 10.3133/pp1499 
9. Freeman MC, Pringle CM, Jackson CR (2007) Hydrologic connectivity and the contribution of stream headwaters to ecological integrity at regional scales. J Am Water Resour Assoc 43:5-14. doi:10.1111/j.17521688.2007.00002.x

10. Fritz KM, Hagenbuch E, D’Amico E, Reif M, Wigington PJ, Leibowitz SG, Comeleo RL, Ebersole JL, Nadeau T-L (2013) Comparing the extent and permanence of headwater streams from two field surveys to values from hydrographic databases and maps. J Am Water Resour Assoc 49:867-882. doi:10.1111/jawr.12040

11. GA DNR (2002) Saint Marys River Basin Management Plan 2002. Georgia Department of Natural Resources Environmental Protection Division. https://epd.georgia.gov/document/publication/st-marys-river-basinmanagement-planpdf/download. Accessed 22 June 2021

12. Gardner RC (2011) Lawyers, swamps, and money: U.S. wetland law, policy, and politics. Island Press, Washington

13. Golden HE, Creed IF, Ali G, Basu NB, Neff BP, Rains MC, McLaughlin DL, Alexander LC, Ameli AA, Christensen JR, Evenson GR, Jones CN, Lane CR, Lang MW (2017) Integrating geographically isolated wetlands into land management decisions. Front Ecol Environ 15:319-327. doi:10.1002/fee.1504

14. Golden HE, Sander HA, Lane CR, Zhao C, Price K, D'Amico E, Christensen JR (2016) Relative effects of geographically isolated wetlands on streamflow: a watershed-scale analysis: Geographically isolated wetlands and streamflow. Ecohydrology 9:21-38. doi:10.1002/eco.1608

15. Gorman TA, Haas CA, Bishop DC (2009) Factors related to occupancy of breeding wetlands by flatwoods salamander larvae. Wetlands 29:323-329. doi:10.1672/08-155.1

16. Gregoire DR, Gunzburger MS (2008) Effects of predatory fish on survival and behavior of larval gopher frogs (Rana acpito) and southern leopard frogs (Rana sphenocephala). Journal of Herpetology 42:97-103. doi:10.1670/07-039.1

17. Holt R, Tanner JM, Smith JR, Patton AC, Lepchitz ZB (2020) Impact of the proposed Twin Pines mine on the Trail Ridge hydrologic system. TTL, Inc. https://twinpinesmineralscharlton.com/wp-content/uploads/2020/01/IMPACTOF-THE-PROPOSED-TWIN-PINES-MINE-ON-THE-TRAIL-RIDGE-HYDROLOGIC-SYSTEM.pdf. Accessed 21 June 2021

18. Jackson CR, Thompson J, Kolka R (2014) Wetland soils, hydrology, and geomorphology. In: Batzer DP, Sharitz RR (eds) Ecology of freshwater and estuarine wetlands, 2nd edn. University of California Press, Berkeley, pp 23-60

19. Johnson SA (2002) Life history of the striped newt at a north-central Florida breeding pond. Southeast Nat 1:381402 doi: 10.1656/1528-7092(2002)001[0381:LHOTSN]2.0.CO;2

20. Jones CN, Ameli A, Neff BP, Evenson GR, McLaughlin DL, Golden HE, Lane CR (2019) Modeling connectivity of non-floodplain wetlands: Insights, approaches, and recommendations. J Am Water Resour Assoc 55:559-577. doi:10.1111/1752-1688.12735

21. Jones CN, Evenson GR, McLaughlin DL, Vanderhoof MK, Lang MW, McCarty GW, Golden HE, Lane CR, Alexander LC (2018) Estimating restorable wetland water storage at landscape scales. Hydrol Process 32:305-313. doi:10.1002/hyp.11405

22. Kirkman LK, Smith L, Golladay S (2012) Southeastern depressional wetlands. In: Batzer DP, Baldwin AH (eds) Wetland habitats of North America: Ecology and conservation concerns. University of California Press, Berkeley, pp 203-215

23. Kusler J, Christie J (2006) State wetland regulatory programs. Association of State Wetland Managers. https://aswm.org/pdf_lib/CQ_state_wetland_regulatory_6_26_06.pdf. Accessed 30 June 2021

24. Lane CR, D'Amico E (2010) Calculating the ecosystem service of water storage in isolated wetlands using LiDAR in north central Florida. USA Wetlands 30:967-977. doi:10.1007/s13157-010-0085-z 
25. Lee S, McCarty GW, Moglen GE, Lang MW, Nathan Jones C, Palmer M, Yeo I, Anderson M, Sadeghi AM, Rabenhorst MC (2020) Seasonal drivers of geographically isolated wetland hydrology in a low-gradient, Coastal Plain landscape. J Hydrol 583:124608. doi:10.1016/j.jhydrol.2020.124608

26. Leibowitz SG, Wigington PJ, Schofield KA, Alexander LC, Vanderhoof MK, Golden HE (2018) Connectivity of streams and wetlands to downstream waters: An integrated systems framework. J Am Water Resour Assoc 54:298-322. doi:10.1111/1752-1688.12631

27. Marton JM, Creed IF, Lewis DB, Lane CR, Basu NB, Cohen MJ, Craft CB (2015) Geographically isolated wetlands are important biogeochemical reactors on the landscape. Bioscience 65:408-418. doi:10.1093/biosci/biv009

28. Meyer JL, Strayer DL, Wallace JB, Eggert SL, Helfman GS, Leonard NE (2007) The contribution of headwater streams to biodiversity in river networks. J Am Water Resour Assoc 43:86-103. doi:10.1111/j.17521688.2007.00008.x

29. Mihelcic JR, Rains M (2020) Where's the science? Recent changes to clean water act threaten wetlands and thousands of miles of our nation's rivers and streams. Environ Eng Sci 37:173-177. doi:10.1089/ees.2020.0058

30. Millennium Ecosystem Assessment (2005) Ecosystems and human well-being: synthesis. Island Press, Washington, DC

31. Nadeau TL, Leibowitz SG, Wigington PJ, Ebersole JL, Fritz KM, Coulombe RA, Comeleo RL, Blocksom KA (2015) Validation of rapid assessment methods to determine streamflow duration classes in the Pacific Northwest, USA. Environ Manage 56(1):34-53

32. QGIS Development Team (2021) QGIS Geographic Information System. QGIS Association

33. Semlitsch RD, Bodie JR (1998) Are small, isolated wetlands expendable? Conserv Biol 12:1129-1133. doi:10.1046/j.1523-1739.1998.98166.x

34. Soil Survey Staff Web Soil Survey. Natural Resources Conservation Service, United States Department of Agriculture. http://websoilsurvey.sc.egov.usda.gov/. Accessed 22 June 2021

35. Subalusky AL, Fitzgerald LA, Smith LL (2009) Ontogenetic niche shifts in the American Alligator establish functional connectivity between aquatic systems. Biol Cons 142:1507-1514. doi:10.1016/j.biocon.2009.02.019

36. Sullivan SMP, Rains MC, Rodewald AD (2019) Opinion: The proposed change to the definition of "waters of the United States" flouts sound science. Proceedings of the National Academy of Sciences 116:11558-11561. doi: 10.1073/pnas.1907489116

37. Sutter LA, Gardner RC, Perry JE (2015) Science and policy of U.S. wetlands. Tulane Environmental Law Journal 29:34

38. Svec JR, Kolka RK, Stringer JW (2005) Defining perennial, intermittent, and ephemeral channels in Eastern Kentucky: Application to forestry best management practices. For Ecol Manage 214:170-182. doi:10.1016/j.foreco.2005.04.008

39. USCRS (2014) The Power to Regulate Commerce: Limits on Congressional Power. U.S. Congressional Research Service RL32844:21.

https://www.everycrsreport.com/files/20140516_RL32844_71079e63225715edd0a732e0934713bad862c7f8.pdf. Accessed 30 June 2021

40. USEPA (2019) Letter from the USEPA to the USACE regarding SAS-2018-00554, Twin Pines Minerals, LLC heavy minerals sand mine in Charlton County, GA. http://wwals.net/pictures/2019-10-03--epa-usace-tpm/epa-usace-tpm2019-10-03.pdf. Accessed 22 June 2021

41. USEPA (2020) EPA and Army deliver on President Trump's promise to issue the Navigable Waters Protection Rule a new definition of WOTUS. EPA Press Office. https://www.epa.gov/newsreleases/epa-and-army-deliver-president-

Page $11 / 13$ 
trumps-promise-issue-navigable-waters-protection-rule-0. Accessed 22 June 2021

42. USEPA SAB (2020) Commentary on the proposed rule defining the scope of waters federally regulated under the Clean Water Act. U.S. Environmental Protection Agency Science Advisory Board.

https://yosemite.epa.gov/sab/sabproduct.nsf/WebBOARD/729C61F75763B8878525851F00632D1C/\$File/EPASAB-20-002+.pdf. Accessed 22 June 2021

43. UWFWS (2019) Letter from the USFWS Athens, GA office to the USACE regarding USFWS file number 2019 - 0963

44. USGS (2021) Rivers and the landscape. USGS Water Science School. https://www.usgs.gov/special-topic/waterscience-school/science/rivers-and-landscape?qt-science_center_objects=0\#qt-science_center_objects. Accessed 21 June 2021

45. Vellut G, Mizutani T (2021) FreehandRasterGeoreferencer

46. Wilcox BP, Dean DD, Jacob JS, Sipocz A (2011) Evidence of surface connectivity for texas gulf coast depressional wetlands. Wetlands 31:451-458. doi:10.1007/s13157-011-0163-x

47. Wipfli MS, Richardson JS, Naiman RJ (2007) Ecological linkages between headwaters and downstream ecosystems: transport of organic matter, invertebrates, and wood down headwater channels. J Am Water Resour Assoc 43:72-85. doi:10.1111/j.1752-1688.2007.00007.x

\section{Figures}

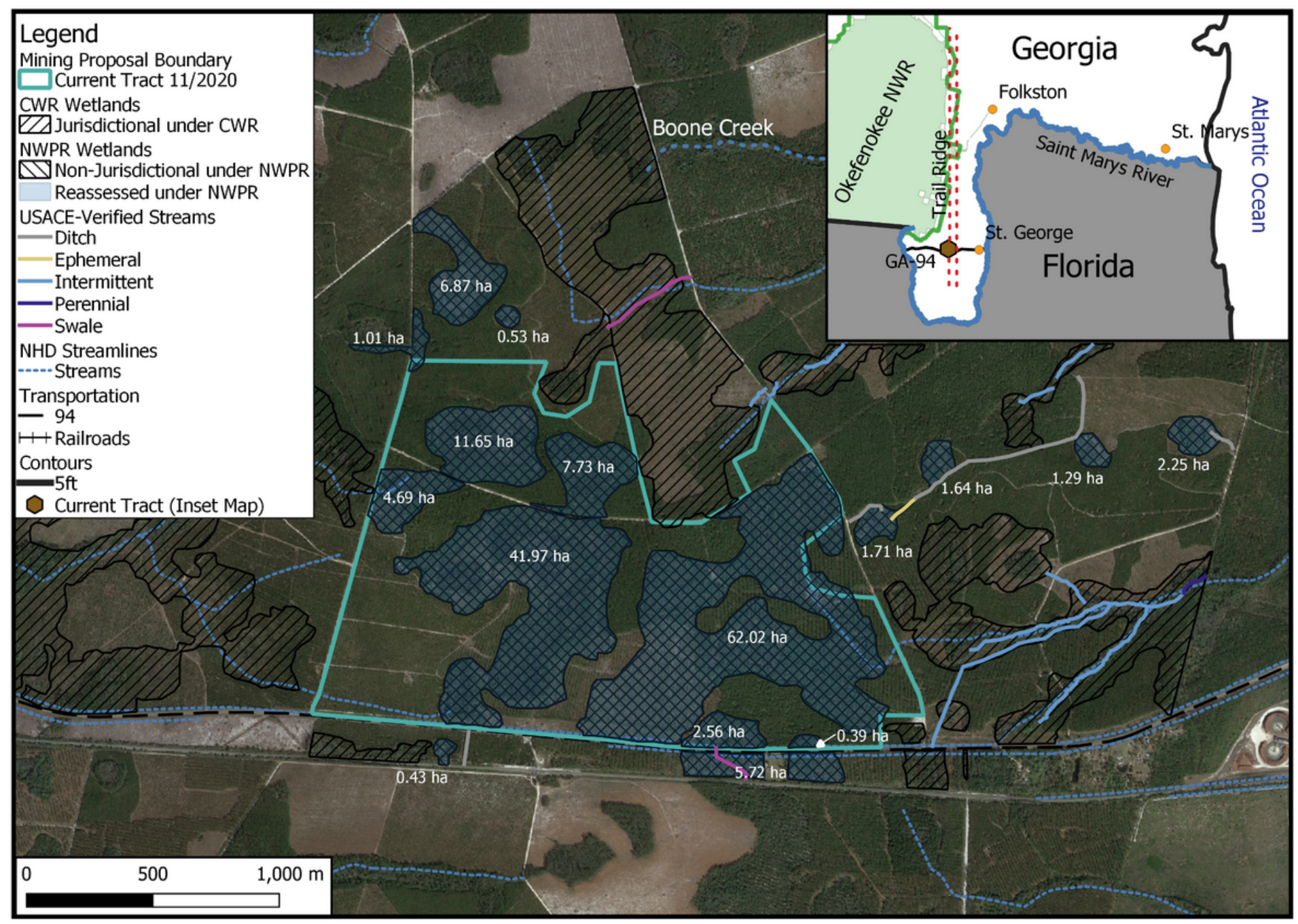




\section{Figure 1}

Current Twin Pines mining proposal tract and setting, including USACE-verified wetlands and streamlines. Inset map shows the proposal location at a larger scale. All wetlands shown were assessed under the CWR and ruled as jurisdictional wetlands. Wetlands reassessed under the NWPR are shown in blue; wetlands that changed to nonjurisdictional after reassessment are crosshatched. Wetland areas are shown on the map in hectares. NHD streamlines shown on the map are DEM-derived and do not necessarily reflect actual streamlines. Base imagery courtesy of the Georgia Geospatial Information Office; flown March 2017. Map created using the Free and Open Source QGIS, version 3.18.1.

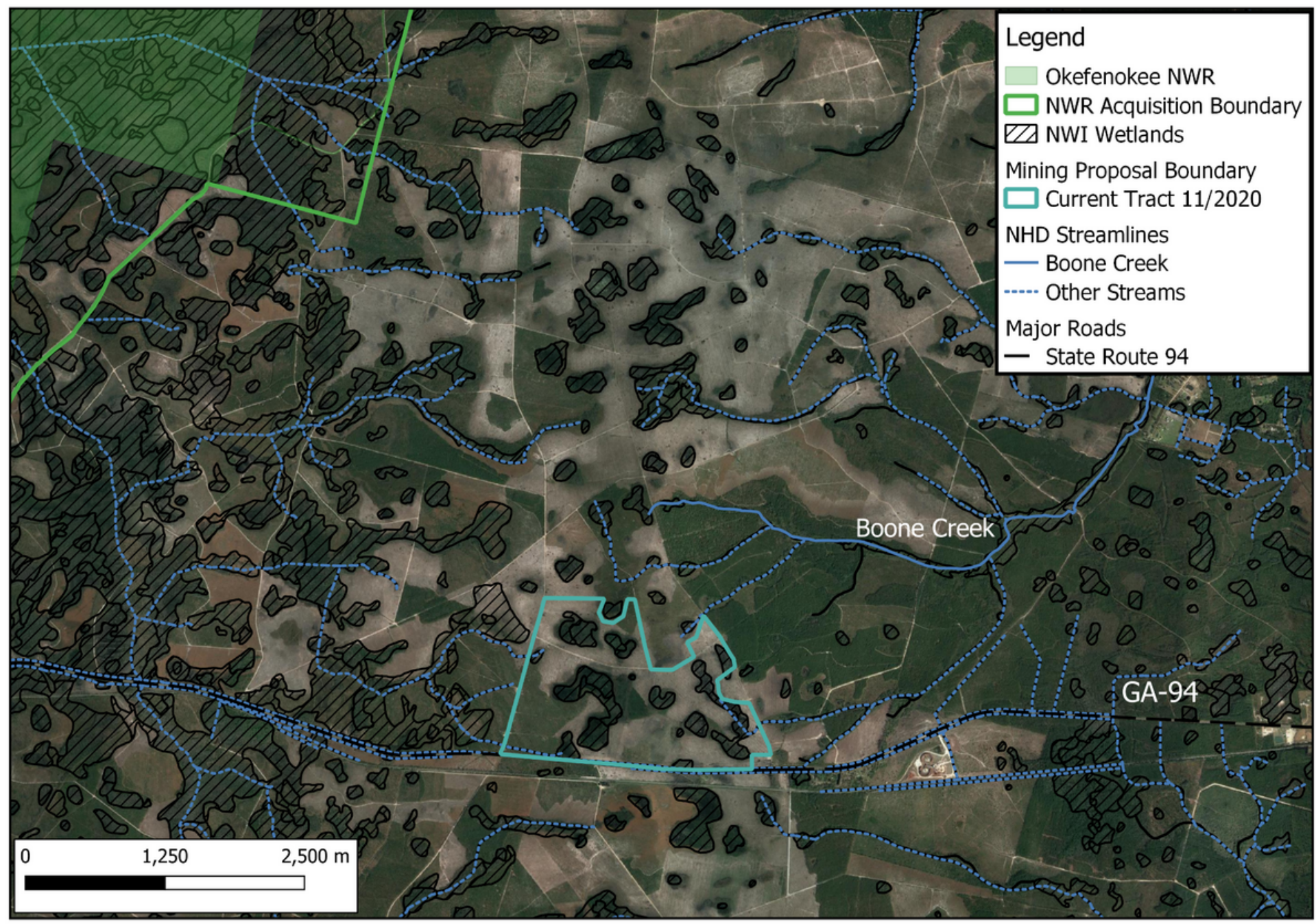

\section{Figure 2}

Larger scale map of current mining proposal tract to show surrounding hydrology. NHD streamlines are DEM-derived and do not necessarily reflect actual streamlines. NWI wetlands are imagery-derived and do not necessarily reflect actual wetlands' locations or extent under USACE definitions. Base imagery is Google satellite image sourced with QuickMapServices plugin for QGIS; flown March 2018. Map created using the Free and Open Source QGIS, version 3.18.1. 